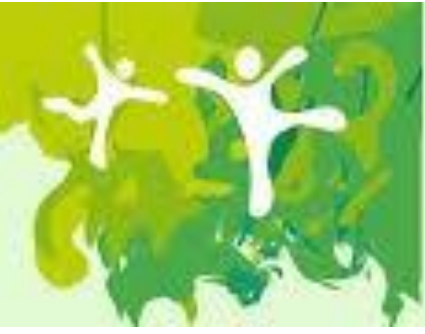

\title{
A VIDA SENDO MODIFICADA NO PROCESSO TERAPÊUTICO: PERCEPÇAO DE FAMÍLIAS DE CRIANÇAS E ADOLESCENTES COM DEFICIÊNCIA VISUAL
}

\section{Pôster}

Autores deste trabalho:

\author{
Mayara Caroline Barbieri: Universidade Federal de São Carlos \\ Gabriela Van Der Zwaan Broekman: Universidade Federal de São Carlos \\ Beatriz Castanheira Facio: Universidade Federal de São Carlos \\ Amanda Aparecida Borges: Universidade Federal de São Carlos \\ Monika Wernet: Universidade Federal de São Carlos \\ Regina Aparecida Garcia de Lima: Escola de Enfermagem de Ribeirão Preto- \\ Universidade de São Paulo
}

Giselle Dupas: Universidade Federal de São Carlos

Área do Trabalho: Enfermagem pediátrica

Número de inscrição: 5532

Data da submissão:30/08/2016 às 07:45

\section{Justificativa}

As repercussões permanentes ocasionadas pela deficiência visual (DV), com necessidades terapêuticas diferenciadas ao longo do tempo, conferem cronicidade à situação, o que pode ocasionar inúmeras dificuldades e modificações na rotina dos membros da família e da própria pessoa com DV.

\section{Objetivo(s)}

Compreender a experiência de famílias de crianças e adolescentes com deficiência visual, com ênfase no processo terapêutico.

\section{Método(s)}

Investigação descritiva, qualitativa que utilizou o Interacionismo Simbólico (IS) como referencial teórico e a Análise de Narrativa como método. Os participantes foram 18 famílias de crianças e adolescentes com deficiência visual, totalizando 61 pessoas. $\mathrm{O}$ 
conceito de família utilizado é proposto por Wright e Leahey. Para a coleta de dados realizamos o genograma, ecomapa e entrevista semiestruturada, gravada, em um único encontro, em local escolhido pela família. A coleta de dados ocorreu no período de novembro de 2014 à julho de 2015. A pesquisa foi aprovada pelo Comitê de Ética em Pesquisa com Seres Humanos, sob número de parecer 748.751

\section{Resultado(s)}

A família se apresenta vigilante na busca incansável pelo diagnóstico e tratamento e ao encontrar um local ou um profissional que melhor corresponda a seus anseios de bom atendimento, passa a confiar nas condutas realizadas pelos especialistas. As propostas de condutas terapêuticas são decididas em família e permeadas por medo, dúvida e esperança. A inserção dos recursos de tratamento e os procedimentos cirúrgicos foram experiências marcantes. A família mostra-se eufórica e com imensa satisfação ao observar as alterações vividas pela criança, suas mudanças no comportamento, passando a ser mais ativa, curiosa, com melhores aquisições no desenvolvimento e no desempenho das Atividades de Vida Diária (AVD’s). As conquistas e a independência estão correlacionadas à boa adaptação aos recursos de tratamento.

\section{Conclusão(ões)}

Mesmo com as dificuldades vivenciadas pela família frente a DV, esta se reestabelece, realiza movimentos próprios ao ir em busca de possibilidades de tratamento e se satisfaz quando esses são resolutivos e melhoram a qualidade de vida e a independência de seus membros. Os profissionais da saúde devem exercer papel de colaboradores no enfrentamento da DV instrumentalizando a família com informações e esclarecimentos necessários sobre a importância e as diversas opções no tratamento. 